\title{
APPLICATION OF CATHODOLUMINESCENCE FOR ON-LINE MONITORING OF REGIME OF AN INDUSTRIAL ELECTRON ACCELERATOR
}

\author{
R.I. Pomatsalyuk, S.K. Romanovsky, V.A. Shevchenko, A.Eh. Tenishev, V.Yu. Titov, \\ D.V. Titov, V.L. Uvarov, A.A. Zakharchenko \\ National Science Center "Kharkov Institute of Physics and Technology”, Kharkiv, Ukraine \\ E-mail: uvarov@kipt.kharkov.ua
}

Continuous monitoring of critical parameters of an industrial electron accelerator provides quality of product processing. For that purpose, the methods of contact-free diagnostics of processing regime are developed. One of them is based on application of a wide-aperture stack-monitor for on-line measurement of beam current, electron energy, and also the mean absorbed dose over the plain of beam scanning in an irradiated object [1]. In the work, the conditions of application of cathodoluminescence (CL), accompanied action of accelerated electrons on amorphous dielectrics, for adjustment of the stack-monitor, and also for measuring in on-line mode the dose in a point of control as well as of distribution of the electron flux density on the surface of the object, is studied. It is shown, that titanium dioxide, keeping the radiation-optical yield at an accumulated dose of up to $4 \mathrm{MGy}$, can be considered as a promising material for manufacturing of CL detector.

PACS: 29.27.Ac; 41.75.Fr; 07.81.+a

\section{INTRODUCTION}

At radiation processing, the demonstration of receipt by every object of absorbed dose within the established range in its minimum $D_{\min }$ and maximum $D_{\max }$ values, is critically important. At an electron accelerator, those parameters are determined by the electron energy, density of the beam current and its distribution over the surface of irradiated load, and also by the velocity of the load transfer through the irradiation zone.

Commonly, the diagnostics of treatment regime on electron energy and absorbed dose is conducted in offline mode with the usage of chemical dosimeters [2]. Adherence of the $D_{\min }$ and $D_{\max }$ values is confirmed with the reading $D_{\text {con }}$ of a checking dosimeter placed in a specified point an the surface of the processed load and the established ratios $\mathrm{D}_{\max } / \mathrm{D}_{\text {con }}$ and $\mathrm{D}_{\min } / \mathrm{D}_{\text {con }}$ [3]. So on-line measurement of $D_{\text {con }}$ and electron energy enables continuous monitoring of processing regime in the absorbed dose.

In the works $[1,4]$, the techniques for on-line measuring of mean electron energy and average absorbed dose over the cross-section of the processed object with the use of a wide-aperture stack-monitor, implemented at a LU-10 accelerator of NSC KIPT (Fig. 1), were described. It was shown, in particular, that the uncertainty of treatment parameters is determined mainly by accuracy of the monitor positioning on the axis of the radiation flux.

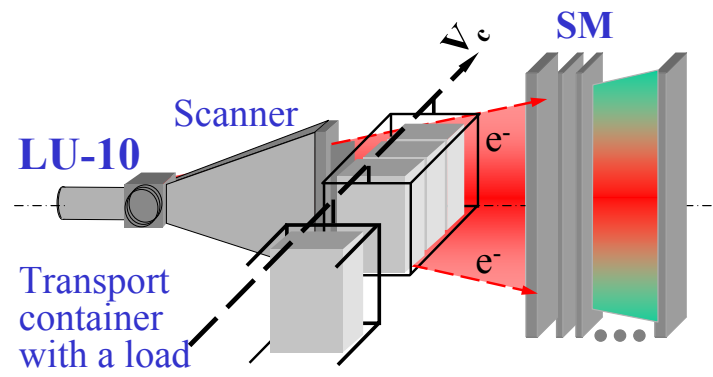

Fig. 1. Output devices of LU-10 accelerator

In this work, the possibility is studied to use the optical radiation induced in various materials exposed to accelerated electrons (cathodoluminescence-CL), for adjustment of measuring devices at output of an industrial electron accelerator, and also for on-line monitoring of product processing regime in the absorbed dose and its distribution over the surface of the product.

\section{CL DIAGNOSTICS}

Incoherent optical radiation is generated at interaction of accelerated electrons with the amorphous dielectrics (see e.g. [5]). Its nature is connected with localization of the quasi-free charges, induced by irradiation in the conduction band of the dielectric with the electron traps in its prohibition zone. It was shown in the work [6], that if the duration of the electron beam pulse, $\tau_{b}$, meets the condition

$$
\tau_{b}<<\frac{N_{D T}^{0}}{n_{C B}} \tau_{C B},
$$

where $N_{D T}^{0}$ - is the concentration of the deep traps (with binding energy of $\sim \mathrm{eV}$ ); $n_{C B}-$ is the concentration of the quasi-free electrons generated in the conduction zone by radiation; $\tau_{C B}$ - is their lifetime, then the flux density of the CL photons is proportional to the absorbed dose rate $\dot{D}$.

So registration of the CL signal on a plane screen with size higher than the width of the electron flux and positioned normally to its axis (a CL radiator) enables visualization of distribution of the flux density in a sighting plane.

If the CL radiator is placed on a container with the processed product, transferred through the irradiation zone with velocity $V_{c}$, then the registration of its optical radiation can be used for measurement of absorbed dose. So if the acquisition interval meets the demand

$$
\tau_{\text {reg }}>\frac{d_{b}}{V_{c}}
$$

where $d_{b}$ - is the lateral dimension of the beam on the object's surface, and at fulfillment of the condition

$$
g \rho D<<N_{D T}^{0},
$$


where $g-$ is the radiation-chemical yield of the deep traps; $\rho-$ is the density of the dielectric; $D-$ is the absorbed dose at its passage of the irradiation zone, then the energy fluence of CL is proportional to the dose.

\section{APPLICATION OF CL FOR STACK-MONITOR ADJUSTMENT}

\subsection{SIMULATION}

A technique of on-line monitoring of electron energy and absorbed dose with the use of a wide-aperture stack-monitor (SM), positioned in the area behind of the treated load, assumes the absorption of major part of the electron flux in SM. This condition is provided by the monitor placement strictly symmetrically relative to the beam scanning plane.

The CL method was used for checking of fulfilment of that demand. Preliminary study of the conditions of its application was conducted by computer modelling on the basis of a transport code GEANT4. In Fig. 2, the calculated distributions of the absorbed dose rate on the surface of first plate of SM at scanning of the LU-10 beam having the spectral maximum of $8.3 \mathrm{MeV}$ (see Fig. 2,a) and 10.7 MeV (see Fig. 2,b), are presented.

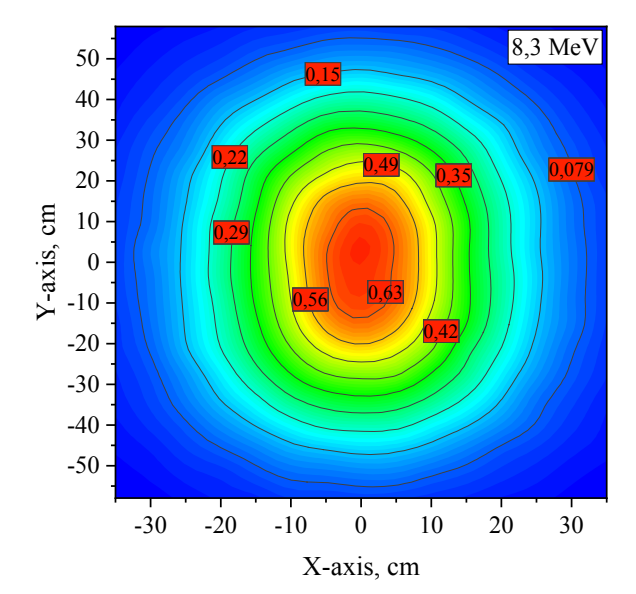

$\mathrm{X} / \mathrm{I}, \mathrm{kGy} / \mathrm{s} / \mathrm{mA}$
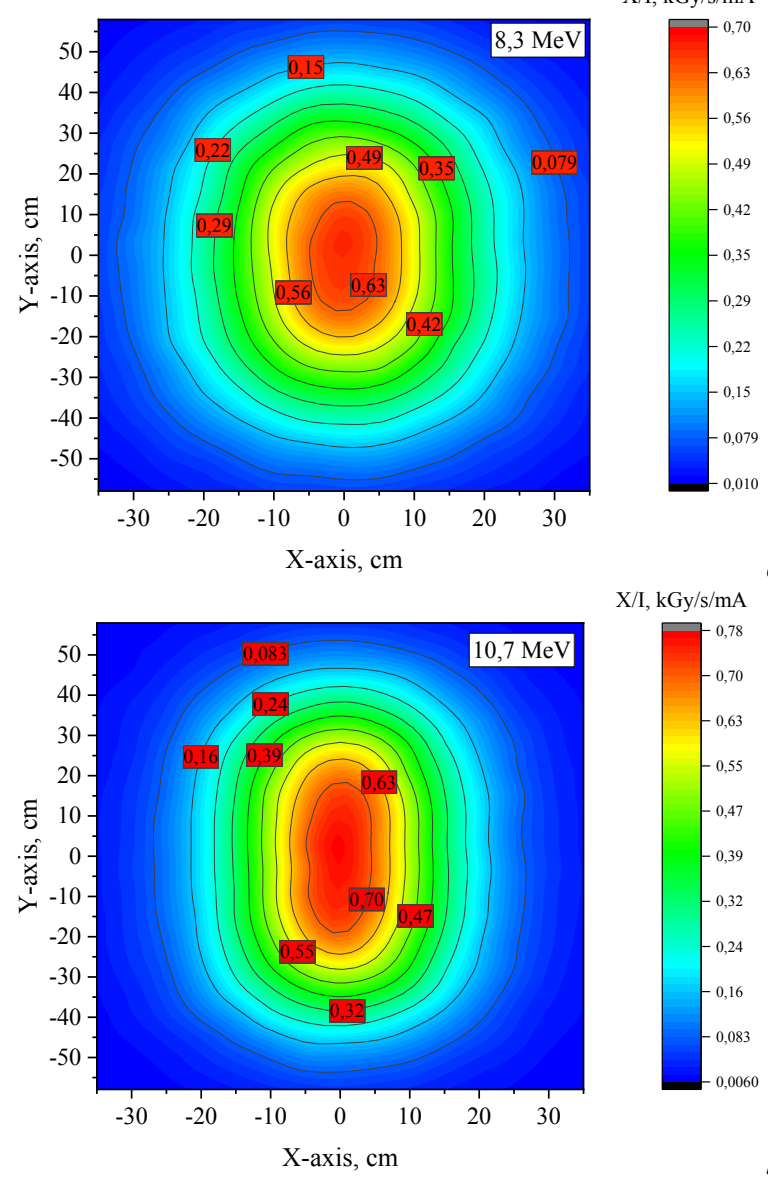

$\mathrm{X} / \mathrm{I}, \mathrm{kGy} / \mathrm{s} / \mathrm{mA}$

$a$

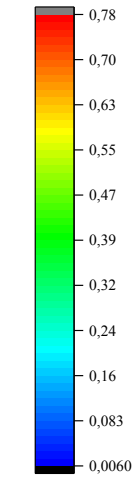

Fig. 2. Maps of normalized absorbed dose rate on surface of stack-monitor: $E_{0, \max }=8.3 \mathrm{MeV}(a)$; $E_{0, \max }=10.7 \mathrm{MeV}(\mathrm{b})$

It is seen, that at a typical average beam current of $1 \mathrm{~mA}$, the dose rate along the scanning axis amounts up to $\sim 0.7 \mathrm{kGy} / \mathrm{s}$. Taking into account the radiation-optical yield of the examined technical materials (cellulose, polypropylene etc. [8]), the exposure of $30 \mathrm{~s}$ is sufficient for recording of optical emission from SM.

\subsection{EXPERIMENT}

For the CL signal registration, a radiator in the form of a carton curtain measuring $1200 \times 850 \mathrm{~mm}$ was set on the SM surface. The horizontal cursors with step of $50 \mathrm{~mm}$, and also two vertical lines were mapped on the radiator. One from the latters revealed the margin of $\mathrm{SM}$, when the other its center. For gain in the radiationoptical yield, a polypropylene film by $32 \mu \mathrm{m}$ in thickness was fixed on the carton also.

In Fig. 3,a, the photo of the glow of the CL radiator, exposed to an electron beam with energy maximum $\mathrm{E}_{0, \max }=8.3 \mathrm{MeV}$, average current of $0.74 \mathrm{~mA}$ and sweep width of $46 \mathrm{~cm}$, is given. A vertical pipe by $80 \mathrm{~mm}$ in diameter being a stationary element of the accelerator exit devices occupies a part of the image. Actually, that element does not stand within the area of the beam action.
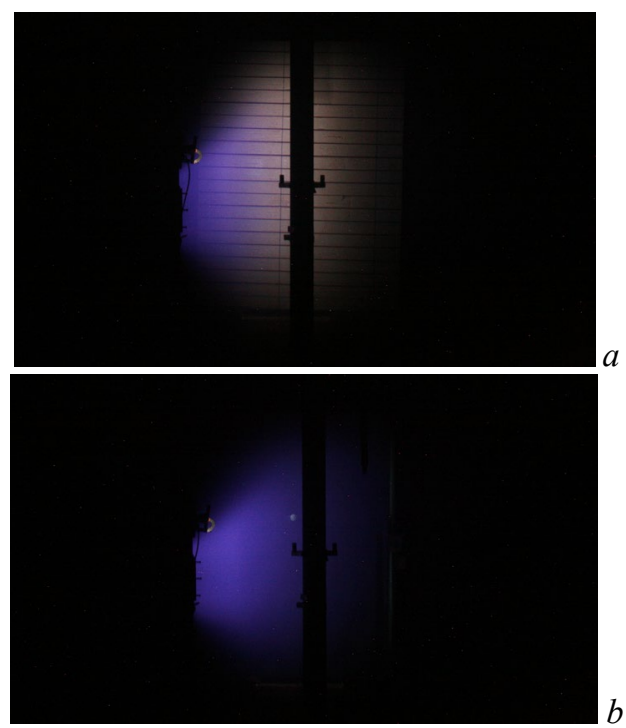

Fig. 3. Optical radiation induced with the electron beam: $C L+$ ionizing radiation (a); ionizing radiation (b)
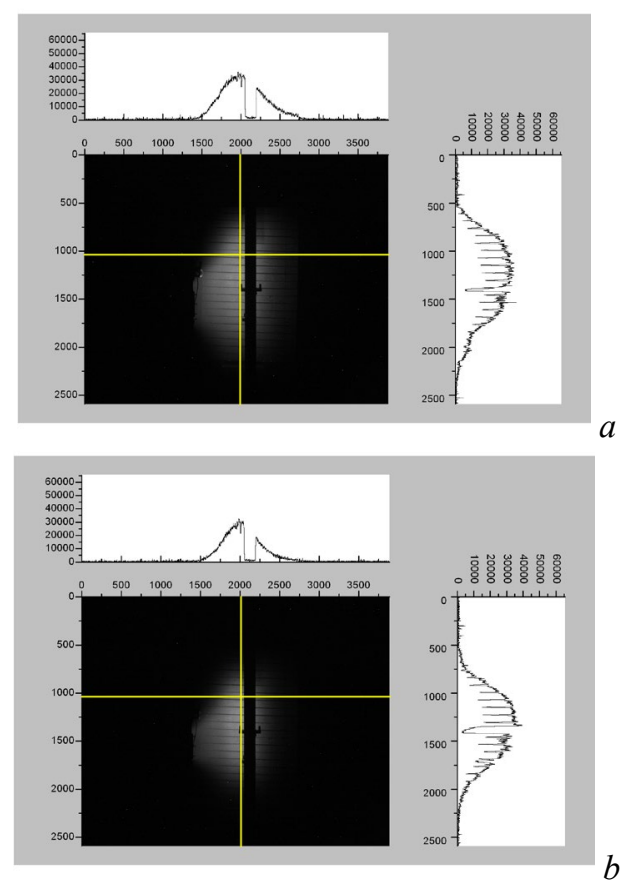

Fig. 4. Horizontal (above) and vertical (on the right) profile of $C L$ intensity on SM surface

at $E_{0, \max }=8,3 \mathrm{MeV}(\mathrm{a})$ and $E_{0, \max }=10,7 \mathrm{MeV}(\mathrm{b})$ 
The optical radiation observed from the point of sight includes, apart from CL, also the ionizing glow of the air (Fig. 3,b). At digital processing of photographs in an Origin medium the latter signal was subtracted as a background (Fig. 4). It should be noted also, that the CL signal and ionizing radiation have different spectra and so can be separated by optical filtering.

In Fig. 5, the results are given of comparison of the dose rate distributions, calculated using the GEANT4 package, and also experimentally measured the CL intensity along the horizontal axis of SM at a spectral maximum of the electron energy of $8.3 \mathrm{MeV}$ (see Fig. 5,a) and 10.7 MeV (see Fig. 5,b).

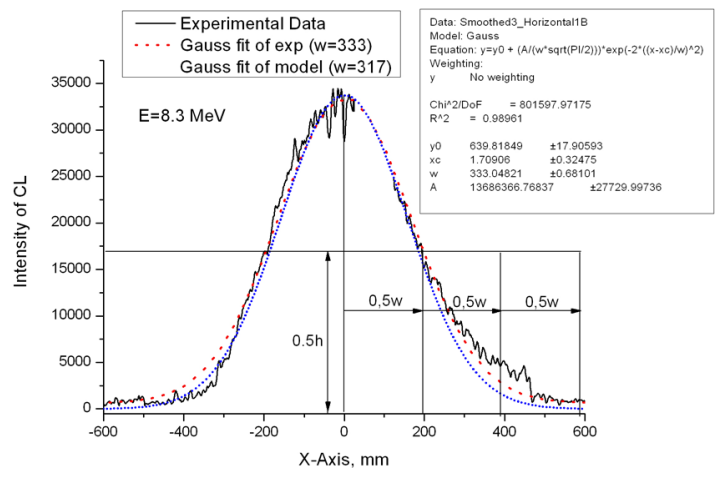

$a$

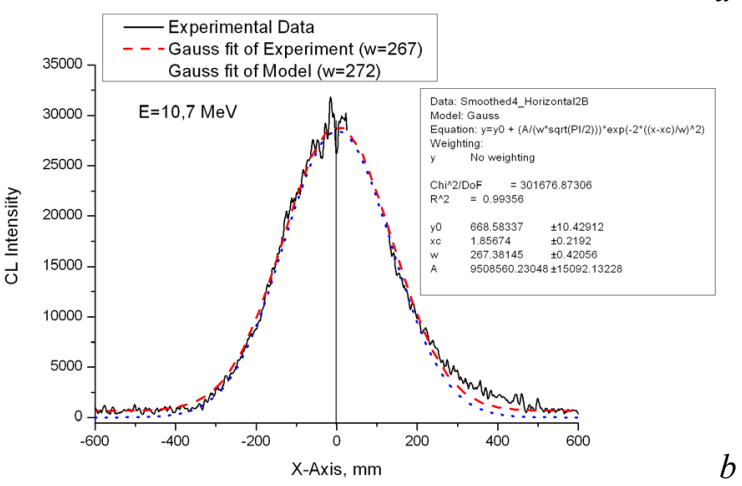

Fig. 5. Comparison of calculated and measured profile of CL intensity and absorbed dose

The results obtained by both techniques are in good agreement. It testifies the tolerable accuracy of the SM adjustment in the electron flux.

\section{CL DOSIMETRY}

As it was shown in the work [7], a number of materials used for product wrapping (carton, polypropylene etc.) are the good CL radiators. At the same time, being technical materials they have unstable characteristics, in particular, as for the radiation-optical yield, and also poor radiation hardness. The latter restricts multiple usage of such a radiator at treatment of industrial scale of a product. That is why the selection and study of materials for a CL detector having stable metrological performance is of special interest.

\section{1. $\mathrm{TiO}_{2}$ AS A CL RADIATOR}

3.1.1. At the choice of the material for a CL detector of absorbed dose, the next criteria were applied:

- the radiation-optical yield to be sufficient for photorecording and linear in a dose span used;

- the minimum effect of the detector on a processing regime;
- the high radiation resistance enables the detector's multiple reusage.

Titanium dioxide $\left(\mathrm{TiO}_{2}\right)$ is well known as an effective white pigment having high radiation durability [8]. A CL detector was developed on its basis in the form of a sheet from duraluminium by $1 \mathrm{~mm}$ in thickness covered with a composite from the water glass and titanium dioxide. The composite was prepared by blending of titanium dioxide of the P-02 brand (in the rutile form), the water glass and the double distilled water in the volumetric proportion $5: 4: 2$. The thickness of the detector was chosen with due regard to its mechanical strength and minimal influence on the process of radiation treatment.

3.1.2. A prototype of the radiator prepared in that technology and measuring $50 \times 450 \mathrm{~mm}$ was fabricated for testing in radiation resistance. The radiator was positioned behind the conveyor with the processed product at a distance of $220 \mathrm{~mm}$ from an exit window of the accelerator in the area of scattered electron radiation and irradiated for 5 hours. The dose accumulated for that period amounted 3.7 MGy. The distant recording of the CL yield was performed using a digital reflex camera. The decrease of the CL yield by the end of irradiation did not exceed $9 \%$.

\subsection{CALIBRATION OF CL DETECTOR}

A prototype of the CL detector by $300 \mathrm{~mm}$ in width was used also for calibration of the detector on the basis of $\mathrm{TiO}_{2}$ against the absorbed dose. The detector was set on a transport container. The dosimeters Harwell Red 4034 (Harwell Dosimeters, UK) were fixed at the edge of the detector $75 \mathrm{~mm}$ higher the bottom of the container. The latter was transferred through the irradiation zone of LU-10 with specified velocity. The CL signal was registered with a digital camera Canon EOS Digital Rebel XT at an exposure of $30 \mathrm{~s}$. This value provided the full optical scanning of area of the beam action at a minimal conveyor velocity of $1.24 \mathrm{~cm} / \mathrm{s}$ providing the absorbed dose of $25 \mathrm{kGy}$. In Fig. 6, the dependence of the relative radiation-optical yield of CL on the dose in a point of registration is given. It is evident, that the dependence is close to linear.

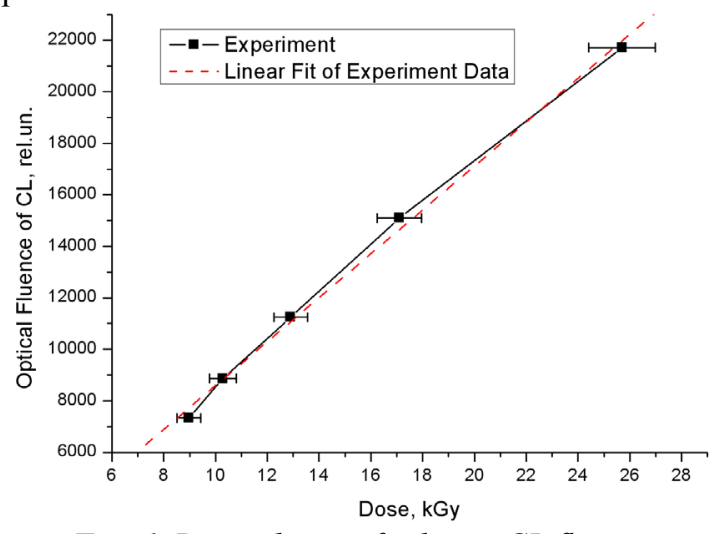

Fig. 6. Dependence of relative CL fluence on absorbed dose

\section{CONCLUSIONS}

Phenomenon of CL induced with high-energy electrons in the technical dielectric materials can be used for visualization of the particle flux profile and adjustment 
of the accelerator output devices. In the technological processes conducting at the electron accelerators, the placement of the CL radiators on the transport containers with an irradiated product enables the on-line monitoring of absorbed dose in a check point at the surface of the product, and also of distribution of the beam density along the scanning axis. A cover on the basis of titanium dioxide can be used as an inexpensive radiator of CL. Such a radiator keeps its radiation-optical yield at an accumulated dose of up to $\sim 4 \mathrm{MGy}$. That provides the possibility of its multiple reusing as an industrial dosimeter.

A CL dosimetry technique can be considered as some development of the known luminescent methods (see e.g. [9]). At the same time, those methods are passive, as they are based on registration of optical radiation induced by various external actions (like heating etc.) on the preliminary irradiated detectors, manufactured from special materials. The proposed technique is active, as it gives dosimetry information directly during irradiation. Besides the new approach is based on the usage of readily available materials.

In contrast to scintillation dosimetry, which is active also, the catodoluminescence technique provides the possibility of high-dose measurement and so enables its application in the radiation technological processes.

\section{REFERENCES}

1. R.I. Pomatsalyuk, V.A. Shevchenko, I.N. Shlyakhov, A.Eh. Tenishev, V.Yu. Titov, D.V. Titov, V.L. Uvarov, A.A. Zakharchenko. Measurement of electron beam energy characteristics at an industrial accelerator // Problems of Atomic Science and Technology. Series "Nuclear Physics Investigations". 2017, № 6, p. 3-7.
2. Standard ISO/ASTM 51649. Practice for dosimetry in an electron beam facility for radiation processing at energies between $300 \mathrm{keV}$ and $25 \mathrm{MeV}$.

3. Standard ISO 11137-1. Sterilization of Health Care Products. Radiation. Part 1: Requirements for Development, Validation and Routine control of a Sterilization Process for Medical Devices.

4. V.L. Uvarov. A method of measurement of absorbed dose in an object exposed to electron radiation. Patent of Ukraine № 111794 // Bull. № 11, 10.06.2016.

5. B.J.M. Brenny, T. Coenen, A. Polman. Quantifying Coherent and Incoherent Cathodoluminescence in Semiconductors and Metals // J. Appl. Phys. 2014, v. 115 , p. 244307.

6. S.K. Romanovsky, V.L. Uvarov. Mechanisms of luminescence of amorphous dielectrics exposed to high-energy electrons // Problems of Atomic Science and Technology. Series "Nuclear Physics Investigations”. 2018, № 3, p. 91-95.

7. S.K. Romanovsky, V.A. Shevchenko, I.N. Shlyakhov, A.Eh. Tenishev, V.Yu. Titov, D.V. Titov, V.L. Uvarov. Dinamics of amorphous dielectrics lyuminescence induced by pulse electron beam // Problems of Atomic Science and Technology. Series “Nuclear Physics Investigations”. 2017, № 6, p. 152.

8. S.A. Yuryev. Optical Properties and Radiation Durability of $\mathrm{TiO}_{2}$ Powders Modified with Nanoparticles of Oxide Compounds // http://static.freereferates.ru/_avtoreferates/01008071 760.pdf

9. M.N. Konopka, B. Odryk. Luminescence Dosimetry: Review of Methods, Detectors and their Application // Nonlinear Optics Quantum Optics. 2017, v. 48(2), p. 133-146.

Article received 04.10.2019

\title{
ПРИМЕНЕНИЕ КАТОДОЛЮМИНЕСЦЕНЦИИ ДЛЯ ОN-LINE МОНИТОРИНГА РЕЖИМА ПРОМЫШЛЕННОГО УСКОРИТЕЛЯ ЭЛЕКТРОНОВ
}

\author{
Р.И. Помацалюк, С.К. Романовский, В.А. Шевченко, А.Э. Тенишев, В.Ю. Титов, \\ Д.В. Титов, В.Л. Уваров, А.А. Захарченко
}

Непрерывный мониторинг критических параметров промышленного ускорителя электронов определяет качество обработки продукции. С этой целью разрабатывают методы бесконтактной диагностики режима обработки. Одним из таких методов является on-line мониторинг тока пучка, энергии электронов и среднего значения поглощенной дозы в плоскости сканирования пучка, основанный на использовании широкоаппертурного стек-монитора. Исследованы условия применения катодолюминесценции (КЛ), сопровождающей воздействие ускоренными электронами на аморфные диэлектрики, для юстировки стек-монитора, а также измерения в on-line режиме величины поглощенной дозы в контрольной точке обрабатываемого объекта и распределения плотности потока электронов на его поверхности. Показано, что в качестве перспективного материала для изготовления КЛ-дозиметра может быть использован диоксид титана, который сохраняет величину радиационно-оптического выхода при интегральной поглощенной дозе до 4 МГр.

\section{ЗАСТОСУВАННЯ КАТОДОЛЮМІНЕСЦЕНЦЇ̈ ДЛЯ ОN-LINE МОНІТОРИНГУ РЕЖИМУ ПРОМИСЛОВОГО ПРИСКОРЮВАЧА ЕЛЕКТРОНІВ \\ Р.І. Помацалюк, С.К. Романовський, В.А. Шевченко, А.Е. Тєнішев, В.Ю. Титов, \\ Д.В. Тітов, В.Л. Уваров, О.О. Захарченко}

Безперервний моніторинг критичних параметрів промислового прискорювача електронів забезпечує якість обробки продукції. 3 цією метою розробляють методи безконтактної діагностики режиму обробки. Одним з таких методів $\epsilon$ on-line моніторинг струму пучка, енергії електронів і середнього значення поглинутої дози в оброблюваному об'єкті в площині сканування пучка, що базується на використанні широкоапертурного стек-монітора. Досліджені умови застосування катодолюмінесценції (КЛ), яка супроводжує дію прискореними електронами на аморфні діелектрики, для юстирування стек-монітора, а також вимірювання в on-line режимі величини поглинутої дози в контрольній точці та розподілу щільності потоку електронів на поверхні оброблюваного об'єкту. Показано, що як перспективний матеріал для виготовлення КЛ-детектора 
може бути використаний діоксид титану, який зберігає величину радіаційно-оптичного виходу при інтегральній поглинутій дозі до 4 МГр. 